\title{
EXPLORING THE RELATIONSHIP BETWEEN MENTORSHIP AND SUCCESSFUL YOUTH ENTREPRENEURSHIP AT TELKOM, SOUTH AFRICA
}

\author{
Belinda Nomacilongo Tshehla*, King Costa**
}

\begin{abstract}
South Africa, in general, is plagued by high unemployment, especially among the youth. The study explored the relationship between mentorship and successful youth entrepreneurship at Telkom, South Africa. The primary focus of the investigation was to establish whether mentorship could be the answer to unemployment and the declining youth entrepreneurship in the City of Tshwane. A qualitative research approach was applied in this study, using the Telkom mentorship programme as the sample. The sample consisted of mentors and youth mentees, obtained from the Telkom mentorship database. Data was collected using semistructured, open-ended interviews. Data analysis was done using thematic analysis with Atlas Ti 8.0.
\end{abstract}

The literature shows that mentoring has benefits for both mentors and entrepreneur mentees. It also shows that the government and private sector can play a key role in youth entrepreneur mentorship. The findings of the study have proven that mentorship yields positive results for youth entrepreneurs, which supports the literature in this study. The findings of the study yielded three themes, which were as follows: success factors for mentorship, inhibiting factors for mentorship, and influence of mentorship on successful youth entrepreneurship. In addressing the objectives of this study, the findings have proven that there is a relationship between mentorship and successful youth entrepreneurship. The recommendations made in this study include improvements in the mentorship programme for mentees and mentors, initiatives by government that include more mentorship programmes and better communication as well as providing funding for mentorship programmes. Further research, to establish the correlation between mentorship and successful entrepreneurship, is recommended.

Key terms: entrepreneur, entrepreneurship, mentorship, mentor, mentee, youth, unemployment 


\section{INTRODUCTION}

The significant role that entrepreneurship plays in global economic growth cannot be overemphasised. As indicated by Ekpe, Razak, Ismail and Abdullah (2016) and Light and Bhachu (2017), there seems to be a greater appreciation for entrepreneurship, as an imperative instrument and driver of sustainable economic growth through employment creation, career advancement and its welfare impact. Extensive research has been undertaken globally to underscore the importance of entrepreneurship and its role in eliciting greater participation of young people in the economy (Hustedde, 2018; Fadeyi, Oke, Ajagbe, Isiavwe \& Adegbuyi, 2015). This is particularly important in Africa, where business analysts and social reporters frequently highlight the way that Africa's population continuous to get younger, while struggling to gain access to employment opportunities (Herrington, Kew \& Mwanga, 2017). According to the Youth Enterprise Development Strategy (2013-2023), youth unemployment contributes $73 \%$ to the total unemployment in South Africa, which is equal to $63.5 \%$ of the youth unemployment rate (StatsSA, 2018). Unemployed youth in South Africa puts an extra burden on a constrained government expenditure plan (Fatoki \& Chindonga, 2011, p. 161).

Entrepreneurship is viewed as one of the solutions to high youth unemployment (Thurik, Carree, Stel \& Audretsch, 2008, p. 682; Ekpe et al., 2016; Herrington et al., 2017). In South Africa, youth entrepreneurship is seen as an integral part of economic growth (National Youth Policy, 2015-2020). Despite some fast-growing economies in sub-Saharan Africa, South Africa continues to be plagued by socio-economic issues, hampering rapid growth of entrepreneurship among its youth population (Gudmastad, 2013). This is further aggravated by a 4\% decrease in entrepreneurial intent, from 2015 to 2016, among 18-34-year olds (Herrington et al., 2017). The South African government, in seeking to help youth entrepreneurs to develop and thrive, has introduced the entrepreneurship mentorship and coaching programme through the Department of Small Business Development (DSBD) (Department of Small Business Development strategic plan 2015 - 2019) With this programme, the government aims to enhance performance, survival rates and profitability of youth-owned and -managed businesses through coaching and mentorship.

The mentorship scheme was recognised as a vehicle that could assist in accomplishing South Africa's key financial goals (Jobs Summit Declaration, 1998). According to Riverin (2007), the primary objective of the business mentoring programme is to assist new entrepreneurs to acquire fundamental managerial skills and to produce positive impacts for the protégé. In the United Kingdom (UK), business mentoring is at the centre of the entrepreneurship ecosystem and $70 \%$ of start-up businesses that have access to it, survive for more than five years 
(Mowgli, 2017). The question is whether mentorship could be the solution to the youth entrepreneurship problem in South Africa? The research question is therefore: What role does mentorship play in promoting youth entrepreneurship in South Africa?

The primary objective of this study was to explore the efficacy of mentorship to foster successful youth entrepreneurship at Telkom, in the City of Tshwane, South Africa.

The secondary objectives are to:

- explore the relationship between mentorship and successful youth entrepreneurship at Telkom

- establish the factors inhibiting mentoring youth entrepreneurs

- explore the role that government and the private sector can play in encouraging mentorship for youth entrepreneurs

The outcome of the research could help policymakers to make informed policy decisions with regard to youth entrepreneurship and the unemployment problem as well as contribute to the body of knowledge on entrepreneurship. It will thus assist future students, academics and researchers in the field of business management.The paper is structured as follows: first, the literature review on entrepreneurship and mentorship is presented; the methodology used to collect the data; then, a report and discussion of the results follows; and, finally, the conclusions and recommendations.

\section{LITERATURE REVIEW}

The literature reviewed in this paper covered the conceptualisation of entrepreneurial mentorship, theory of entrepreneurial mentorship, mentorship of youth entrepreneurs, mentorship success and benefits and concluded by discussing mentorship at Telkom.

\section{Conceptualisation of entrepreneurial mentorship}

Mentorship is not a foreign concept in entrepreneurship, in fact, it was discovered by Srivastava (2013) as a conceivable answer for issues confronted by start-up entrepreneurs. Pelan (2012) defines mentoring as a process where a mentor helps a mentee to succeed by providing guidance towards achieving practical skills. The benefits of mentorship in entrepreneurship cannot be overemphasised, as identified by Connor (2014), who holds that mentorship is an important factor in building youth entrepreneurs. Entrepreneurial mentorship is defined as the process of nurturing and supporting entrepreneurs (Hisrich \& Peters, 2002). On the other hand, Laukhuf and Malone (2015) view mentors in entrepreneurship as creators 
of entrepreneurial positive results, while Kyrgidou and Petridou (2013) consider mentorship to be an important commitment in starting and growing a business. Mentorship, as observed by St-Jean (2011), is an essential requirement for entrepreneurs in proceeding with their expert improvement. >Olsen (2011), further, affirms that mentorship is fundamental in guaranteeing the success for future entrepreneurs. The benefit of mentorship is that one can develop and grow as an entrepreneur independently (St-Jean \& Audet, 2009).

Mentored youth are associated with positive results and progress, even though the benefits of mentoring have not been properly measured quantitatively (Mckevitt \& Marshall, 2015; Pompa, 2012). However, mentoring programmes have been associated with improved and increased opportunity for attaining employment, advancing business skills and enhancing career outcomes (Ragins \& Kram, 2007). According to Jekielek, Moore, Hair and Scarupa, (2002, p.6) and Beattie (1999), mentoring entrepreneurs in the early stages of their careers yields benefits in their business. Schøtt, Kew and Cheraghi (2015) assert that skills development and market access is unlikely to produce a significant increase in youth entrepreneurial activity, without a concomitant investment in mentoringOzgen and Baron (2007) and St-Jean and Audet (2013) associate mentored youth with high self-esteem, selfconfidence, improved abilities for goal achievement, problem solving, learning, dealing with change and doing business, enhanced contact network and knowledge and opportunity recognition and entrepreneurial self-efficacy. Mentorship has positive benefits - the question is whether these benefits can be linked to successful youth entrepreneurship.

\section{Theory of entrepreneurial mentorship}

There are many and varied theories relating to entrepreneurial mentorship (Haggard, Dougherty, Turban \& Wilbanks, 2011). Some of the theories perceive entrepreneurial mentorship as direct aspects of management and business operations as well as access to business networks. According to Ladzani and Van Vuuren (2002, p.157), entrepreneurship training is one of the basic requirements of starting and running a business. Sullivan (2000, p.165), on the other hand, emphasises the personalised learning process as a valuable tool for developing business skills. However, Ladzani and Van Vuuren (2002:156) see business skills training as including general management, marketing management, production management, financial management, pricing calculations, costing and legal skills rather than other categories of skills. Counter to this view, Sullivan (2000, p.172) points out that mentorship enhances psychological traits of competence, clarity of identity and effective assumption of a professional role. Bisk (2002) concurs with this view by providing factors required to give effect to the learning process and business skills development. These factors 
are as follows: value systems, self-worth, personal advice and interpersonal relationships. The latter factor, as substantiated by Sullivan (2000, p.172), involves friendship, support, acceptance, counselling and role modelling to mentees.

According to Mason (2011), mentoring can be formulated as a form of practical instructions. Internationally, the practice of mentoring was said to help entrepreneurs face their business management challenges and proactively confront barriers. A key success factor was reported to be the ability to ask for help (Laukhuf \& Malone, 2015). Mentors were collaborators, who helped mentees to work through their business and personal issues (Aubert, 2014). Mentorship has been revealed as a valuable part of the training provision to support SME growth and overcoming failure in Canada (Audet \& Couteret, 2012).

Entrepreneurial mentoring is also characterised as practical programmes that provide business management skills to entrepreneurs (Bechard \& Toulouse, 1998; Vesper, 1990). Within this process, there is a dispensing of practical skills and acquisition of the attitudes required for effective management of business ventures (Rasheed \& Rasheed, 2007). St Jean and Audet (2012) contextualise entrepreneurship mentoring further and explain that it facilitates a more efficient and secured transfer of complex experiences into learning and practice. They argue that the provision of personalised, flexible support, tailored to each particular situation, is generally seen as crucial for the success of mentorship. They, however, advise that mentoring should come earlier in the entrepreneurial process in order to influence career satisfaction and retention of novice entrepreneurs.

\section{Mentorship of youth entrepreneurs in South Africa}

The role of mentorship in youth entrepreneurship cannot be over-emphasised. Many studies have highlighted the critical role of mentorship of youth entrepreneurs in achieving business success (St-Jean \& Mathieu, 2015; Memon et al., 2015; Maina, 2016). According to St-Jean, and Audet (2012) and St-Jean and Mathieu (2015), mentorship empowers individual entrepreneurs to become better business professionals and managers. Youth entrepreneurs gain a better business attitude and confidence through mentorship programmes (Memon et al., 2015; Maina, 2016). Memon et al. (2015) also identify mentorship as an important factor in the development of an entrepreneur as an individual.

Mentorship schemes have been recognised as vehicles geared towards driving South Africa's key economic development goals and social change initiatives (Jobs Summit Declaration, 1998, p.3). The South African government, in seeking to help youth entrepreneurs to develop 
and thrive, introduced entrepreneurship mentorship and coaching programmes through the DSBD, NYDA, Ithubalentsa Micro Enterprise Programme and Accelerate Cape Town mentorship pilot programme (2017). With these programmes, the government aims to enhance the performance, survival rates and profitability of youth-owned and -managed businesses.

The South African private sector has also embraced entrepreneurial mentorship in support of the South African government entrepreneurship initiative. This is particularly true is the case of Telkom SA, which is a private company that has implemented a youth entrepreneur mentorship scheme. This scheme has proven positive results in encouraging and ensuring the success of existing and future youth entrepreneurs (Telkom Mentorship Programme, 2018).

\section{Mentorship success and benefits}

According to several researchers, one of many sources of start-up business failures is a lack of experience and professional competency on the part of new entrepreneurs. Their inadequacies are evidenced by a lack of business vision and an inability to find a profitable niche for their new business ventures (Gaskill, Van Auken \& Manning, 1993; Baldwin, Gray, Johnson, Proctor, Rafiquzzaman \& Sabourin, 1997). Upon closer observation of business trends, it appears that an exponential increase of an entrepreneur's skills and knowledge, within the first year of a company's life, is a determining factor in its eventual survival (Gartner, Starr \& Bhat, 1999). Some researchers even claim that entrepreneurial mentoring can influence business growth and sustainability (Deakins \& Freel, 2006; Priyanto \& Sandjojo, 2005). Shepherd (2011) views mentorship as an essential factor in entrepreneurial success.

Mentorship employs various mentoring schemes that differ in approaches and, as a consequence, vary in the measure of benefit and success. Mentorship is a personal developmental relationship, in which a more experienced person takes a less experienced person "under their wing" (Beckett, 2010). The significance of mentorship is underpinned by its successes in various areas and spans different disciplines of interest. According to St Jean (2012), success in mentorship is achieved when the mentorship objectives have been met. However, the most significant predictor of positive mentoring results is whether mentors and mentees share a close, trusting relationship that includes ongoing support and monitoring. As noted by Gallup (2014), success in mentorship lies in the success of the mentorship relationship. Rhodes, Spencer, Keller, Liang and Noam (2006) remonstrate that close mentoring relationships result in enhancement of social and emotional development; improvements in cognitive functioning through conversation, joint activity and guided 
instruction; and promotion of positive identity development. One of the key factors that places significance on mentorship is self-esteem. In fact, the nature of mentoring relationships, particularly mentorships that emphasise a close, caring and supportive relationship between the mentor and mentee, is particularly well suited to mentoring and results in the development of self-esteem (Schwartz, Lowe \& Rhodes, 2012).

According to Kubicek (2007), successful mentorship includes the following characteristics: aligns with organisation objectives; enjoys organisation-wide senior management support; meets the specific developmental needs of mentees; recognises contributions of mentors; offers training, orientation and networking opportunities; establishes realistic and time-bound milestones; launches with a written, signed commitment; respects confidentiality of the relationship; and recognises successful outcomes.

According to Dinolfo and Nugent (2010), formal mentoring makes a positive impact on organisations, mentors and mentees. For a mentorship programme to succeed, it requires structure, planning, organisational buy in and commitment (ibid). Dinolfo and Nugent (2010) note that effective mentoring programmes have formal goals, which are outlined and tracked; have designated minimum time commitments; formal processes for monitoring the relationship and to ensure that both parties are held accountable; links to talent management; links to the business strategy; and it aims to match mentors and mentees based on skills/development needs.

\section{Drivers for entrepreneurial mentorship success}

Raeesi, Dastranj, Mohammadi and Rasouli (2013) postulate that, in general, drivers and barriers are either internal or external. Barker, Rendon and Janis (2014) posit that for mentorship to be successful, key drivers need to be in place. According to Podsen and Denmark (2000), goal and objective setting is an important driver for successful mentorship. The achievement of mentorship goals leads to the success and expansion of the programme, where mentees can also become mentors (Cranwell-Ward et al., 2004; Bickel \& Brown, 2005). According to Padilla, Mulvey and Lunsford (2010), goal-orientated activities are key to the success of mentorship. In designing the mentorship programme, it is important to set goals and objectives in order to measure the success thereof and to improve the programme, if there is a need. Through goal setting, mentors can assist mentees to define what they want to achieve through the mentorship programme, plan ahead and be accountable, and increase their motivation to achieve their goals (Bickel \& Brown, 2005). 
For any programme to be successful, support is vital. According to Cranwell-Ward et al. (2004), the support of key stakeholders is pivotal for mentorship programme success. With support, commitment can be achieved from the organisation and all parties involved in the mentorship programme (Klasen \& Clutterbuck, 2002).

One of the key drivers to mentorship success is the relationship between the mentor and the mentee. Stephens, Heaphy and Dutton (2012) view the mentorship relationship as the development of high-quality interactions, which provide support in the form of psychosocial, instrumental and positive interactions. According to Myall, Levett- Jones and Lathlean (2009), the nature and quality of the relationship between mentors and mentees continues to be fundamental to the mentoring process and success. According to Sambunjak, Straus and Marusic (2009), the mentoring relationship is at the core of the mentorship programme, with an emphasis on honesty, trust, mutual respect, open communication and confidentiality.

A definition of the roles in the mentoring process is also critical in mentorship. Mentoring involves guidance and support through difficult situations that results in building up of selfconfidence as well as personal and professional development. Myall et al. (2008) have identified the mentor as a practitioner, who facilitates learning and supervises and assesses students in the practice setting. They further state that the responsibility of the mentor should include provision of support and guidance in the practice area; facilitation of mentee learning; assessment and evaluation of the mentee; acting as a positive role model; and ensuring mentees are fit for purpose, practice and award.

Benefits and successes associated with mentorship programmes have influenced many organisations in establishing formal mentor-mentee relationships among its newcomers and existing members (Van der Sijde \& Weijman, 2013). Mentorship yields benefits to both the mentor and the mentee. According to Podsen and Denmark (2000), collaboration is a benefit received from mentoring. This is further emphasised by Griffin, Winn, Otis-Wilbor and Kilgore (2003), who assert that the positive results yielded by mentorship include collaboration, skills improvement and enhanced self-confidence as well as benefits to the mentor. The benefits of a mentorship programme for the mentee are of a personal and a business nature. An effective mentorship relationship facilitates the development of independence, self-confidence, job satisfaction, upward mobility, and decision-making/problem-solving skills in the protégé (Shrubbe, 2004). Morton-Cooper and Palmer (2000) designed the following table to list the mentorship benefits for both the mentor and mentees. 
Table 1: Benefits to mentors and mentees

\begin{tabular}{|c|c|}
\hline Mentee benefits & Mentor benefits \\
\hline Positive attitude & Ability to share network contacts \\
\hline Willing to take risks & Coaching and counselling skills \\
\hline Potential to succeed & Confidence \\
\hline Decision making & Risk taking \\
\hline Sound judgement and creativity & Commitment \\
\hline Being motivated & Satisfaction \\
\hline Networking & \\
\hline
\end{tabular}

\section{Barriers to youth entrepreneurial mentorship}

Despite the best effort of mentors, there are, broadly-speaking, factors that impede the success of mentorship. According to Klasen and Clutterbuck (2002), it is important to address the barriers associated with the successful mentorship programmes. In order to resolve these barriers, one needs to identify them. Klasen and Clutterbuck (2002) identified the following as some of reasons for failure in the mentorship programmes: (1) poor planning and preparation; (2) inadequate mentors; (3) lack of mentorship skill; (4) lack of clarity on roles and responsibilities; and (5) inadequate support from the top. Additionally, Franklin, Turner, Kariuki and Duran (2001) identified access, time, assessment and vision as barriers to mentorship. Marco and Perina (2004) also emphasise the lack of mentor networks as a hinderance that can affect the success of mentorship, as a mentor network may assist in the pairing of proteges with the right mentor.

\section{- Poor planning and preparation}

One of the key requirements for a successful mentorship programme is a mentorship contract, with clear commitments and needs, to be signed by both mentor and mentee (Kubicek (2007). Without a contract, there will not be clear objectives, which should lead to clear milestones. St Jean (2012) agrees with this view. According to him, success in mentorship is achieved when the mentorship objectives have been met. According to Dinolfo and Nugent (2010), for a mentorship programme to succeed, it requires structure and planning.

\section{- Inadequate mentors}

Without sufficient mentors it becomes a challenge to run a successful mentorship programme. Higgins and McCarthy (2005) argue that when the number of mentees is too large for the available mentor, this renders the mentors less effective. 


\section{- Lack of mentorship skills}

Not everyone is a mentor; mentorship skills are learned. It is vital for the mentee-mentor match to be done correctly. As stated by Kubicek (2015), matching mentors to mentees, according to their profiles, is key to the success of the programme.

\section{- Lack of clarity on roles and responsibilities}

For a mentor-mentee relationship to work, there should be clear roles and responsibilities (St Jean, 2012). Without clear roles and responsibilities, mentorship objectives cannot be achieved. Gallup (2014) attributes success in mentorship to the success of the mentorship relationship.

\section{- Inadequate support from the top}

Kubicek (2007) places organisation alignment to the mentorship programme at the core of the success of mentorship, in fact, he points out that successful mentorship programmes enjoy support from senior management. Top management support is a key enabler to mentorship. According to Dinolfo and Nugent (2010), no mentorship programme can succeed without organisational buy in and commitment. Kubicek (2007) further states that mentors need to be recognised and this will not be possible without support from the top.

\section{- Access}

According to Franklin et al. (2001), access to support and improve functional, management and technical skills are key barriers to mentorship; however, Ralph (2009) identified access to mentors that match the protégé's expectations as a major barrier to mentorship. Additional to that, the desired mentor characteristics include the mentor's personality, interpersonal abilities and professional status (Sambujak et al., 2009). However, it is desired that mentees possess characteristics that include taking the initiative, having a commitment to the success of the relationship, having a passion to succeed in their career, being willing to learn, being selective in accepting a mentor's advice, being prepared for mentorship meetings, undertaking to complete agreed upon tasks, responding honestly to feedback, performing self-reflection, and having the courage to face their weaknesses and make changes (Sambujak et al., 2009).

\section{- Vision}

Mentorship requires purpose, as there is a lot of time and resources that are invested in this undertaking. Scannapieco and Painter (2014) remonstrate that the lack of understanding of its purpose and importance can result in disruption of the mentoring relationship. Barriers to mentorship exist, if the mentor does not have the appropriate skills to mentor. Mentors, who 
are not prepared adequately for the unique issues of mentorship, are cited as a barrier. A vision on how the tools they have at their disposal can be of value in their future endeavours is required.

\section{- $\quad$ Time}

For mentors, lack of time is also a significant impediment to mentorship (Barker, Rendon \& Janis, 2014). Making time for mentorship is important to ensure the success of the mentorship program.

It is, however, important to overcome barriers in mentorship in order to have an effective mentorship relationship. Overcoming barriers to successful mentorship requires a multifaceted approach. According to Sambujak et al. (2009), the strategies that can be employed to overcome mentorship barriers include, inter alia, targeting the personal aspects, relational aspects and structural aspects of mentoring.

\section{Mentorship at Telkom}

The Telkom Mentorship Programme was established in 2010, with the objective to build a mentorship base, where both mentors and mentees can grow personally and in term of business (Telkom Mentorship Programme, 2018). The secondary objective of this programme is to offer mentees the opportunity to be partnered with a more experienced mentor, who will develop them in areas of personal leadership, business skills and career development (ibid).

Telkom maintains that effective business mentors can be catalysts to a positive business direction and boost the business from barely surviving to actively thriving (www.telkom.co.za). The programme focuses $80 \%$ on building leadership capability (personal leadership, business leadership, thought leadership, market leadership and people leadership) and $20 \%$ on building functional capability (Telkom Mentorship Programme, 2018).

The Telkom Mentorship Programme has been phenomenally successful and currently boasts a total of 40 mentors and 160 mentees. It is also heartening that about $5 \%$ of the mentees have started their own businesses, outside of Telkom, $90 \%$ have grown into senior leadership positions inside and outside of Telkom, and the remainder are also adding considerably more value in their current positions (Telkom Mentorship Programme, 2018).

The benefits of the Telkom Mentorship Programme are:

- enhanced strategic business initiatives

- encourages retention 
- reduced turnover costs

- improved productivity

- breaks down the "silo" mentality that hinders cooperation between company departments or divisions

- elevates knowledge transfer - from just getting information to retaining the practical experience and wisdom gained from long-term employees

- enhances professional development

- links employees with valuable knowledge and information to other employees in need of such information

- encourages on-the-job training, which can have a greater impact than classroom training

- makes use of our own employees, instead of outside consultants, as internal experts for professional development, thereby reducing the cost

- supports the creation of a multicultural workforce by creating relationships among diverse employees and allowing equal access to mentoring

- creates a mentoring culture, which continuously promotes individual employee growth and development

- builds business networks

\section{METHODOLOGY}

The study was done by conducting qualitative research, using the Telkom Mentorship Programme as the sample. The sample consisted of mentors and youth mentees, identified through the Telkom mentorship database. The total population was 200 and consisted of 40 mentors and 160 mentees (Telkom mentorship database, 2018). The study used the purposive sampling technique to select 10 youth entrepreneurs and 10 mentors. A selfselection sampling strategy was used for this research, as this strategy enabled the researcher to select the study's participants, based on the researcher's subjective judgement (Saunders, Lewis \& Thornhill, 2016).

Data was collected using semi-structured, open-ended interviews developed from the literature study. The researcher, with the assistance of one fieldworker, collected the data from the 10 mentors and 10 mentees. The analysis was performed using a computer aided software, ATLAS.ti 8.0, following Braun and Clarke's six phase approach (Braun \& Clarke, 2006). In stage one, the researcher familiarised herself with the verbatim transcribed data. In stages two to four, the data was coded and the codes were consolidated to form subthemes, after which themes were developed from the subthemes. The data was line-on-line coded, 
based on a predetermined framework. During the activity of developing themes, the researcher coded the qualitative data, which resulted in frequency counts. In stage five, the refined themes were examined and, in the last stage, the report was written to present the findings.

\section{RESULTS}

The results were based on data collected from 20 interviews, from which 128 codes were derived and there were no new codes after 16 of the interviews. This means that the last two interviews, for both the mentors and the mentees, respectively, did not yield any new information.

Table 2: Consolidated codes

\begin{tabular}{|c|c|}
\hline \multirow{8}{*}{ Theme 1} & Growth in mentors and mentees \\
\hline & Skilled and knowledgeable individuals \\
\hline & Well-informed individuals \\
\hline & Mentee exposure into product environment \\
\hline & Exposure on management and stakeholder activities \\
\hline & Positive feedback from mentees \\
\hline & Creates employment opportunities \\
\hline & Goal realisation \\
\hline \multirow{9}{*}{ Theme 2} & Lack of role models \\
\hline & Lack of enough information \\
\hline & Lack of willing and capable mentors \\
\hline & Poor commitment \\
\hline & Lack of resources \\
\hline & Social impact \\
\hline & Lack of programme awareness \\
\hline & Mentor and mentee alignment \\
\hline & Current education system \\
\hline \multirow{7}{*}{ Theme 3} & Successful business owners \\
\hline & Open networking channels \\
\hline & Shape career goals \\
\hline & Provides guidance \\
\hline & Develops skills and competencies \\
\hline & Ability to be open minded \\
\hline & Self-confidence \\
\hline
\end{tabular}


These codes yielded three themes, namely, Success factors of mentorship, Inhibiting factors for mentorship success, and Influence of mentorship on successful youth entrepreneurs.

The 128 codes were filtered and consolidated - including potential duplications - resulting in a total of 24 consolidated codes (table 5.3). These are the groups which were used to develop the themes.

Theme 1 was developed to understand the success factors of mentorship. There was a total of eight consolidated codes that were extracted from the interviews with the mentors that support this theme. The mentees were also interviewed and shared their views on their experiences during the mentorship programme.

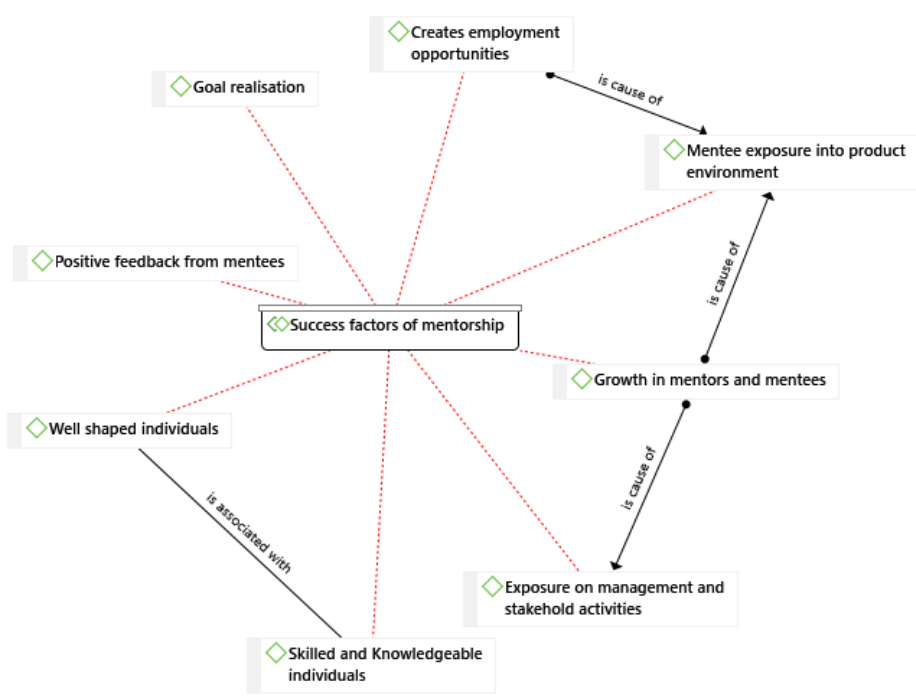

Figure 1: Map of success factors in mentorship

Theme 2 was conducted to understand what the hindrances are that constrained mentorship success, according to the views of the mentors. There was a total of nine consolidated codes that were developed to support this theme. The mentees also gave their personal views on the inhibiting factors in support of or in opposition to the views of the mentors. 


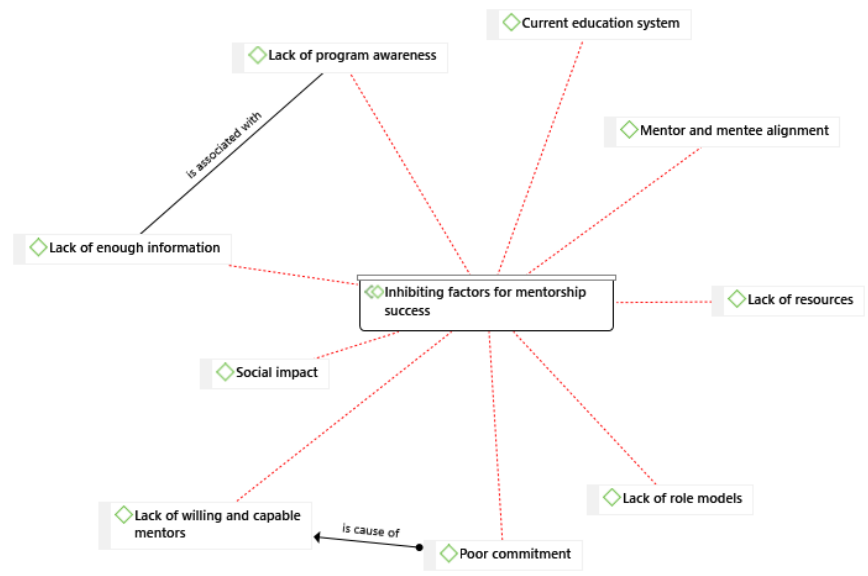

Figure 2: Map of inhibiting factors to mentorship success

Theme 3 speaks to the influences of mentorship on successful youth entrepreneurs, according to the mentors' views.

Table 3: Influence of mentorship on successful youth entrepreneurs

\begin{tabular}{|l|l|}
\hline \multirow{4}{*}{$\begin{array}{l}\text { Theme 3: Influence of mentorship on } \\
\text { successful youth entrepreneurs }\end{array}$} & Successful business owners \\
\cline { 2 - 2 } & Open networking channels \\
\cline { 2 - 2 } & Shape career goal \\
\cline { 2 - 2 } & Provides guidance \\
\cline { 2 - 2 } & Develops skills and competencies \\
\cline { 2 - 2 } & Ability to be open minded \\
\cline { 2 - 2 } & Self-confidence \\
\hline
\end{tabular}

\section{DISCUSSION}

In this study, the findings indicated that successful mentorship is characterised by a wellinformed mentee, with developed skills and knowledge. Mentorship, when done well, will culminate in positive feedback from the mentees about the mentors, as it effected personal growth for both the mentors and mentees.

It has been found that skills and knowledge development are likely to be present in a mentee who is exposed to the critical aspects of entrepreneurship. These aspects include management, stakeholder engagements, exposure to the product and market environment, and the realisation of the mentorship programme goals. This finding places the mentor at the 
centre of mentee development in a mentorship relationship. Myall, Levett-Jones and Lathlean (2008) also recognise the important role that the mentor, as a practitioner plays a crucial part in facilitating learning, supervision and assessment of the mentees in a mentorship relationship. This supports the views of the participants of the study, when they emphasised the need for skills development in mentorship. Myall et al. (2008) further highlight the importance of including the following factors: support and guidance in the practice area, facilitation of mentee learning, assessment and evaluation of the mentee, acting as a positive role model, and ensuring the mentees are fit for purpose and are rewarded accordingly.

The nature and quality of the relationship between mentors and mentees continue to be fundamental to the mentoring process and success. Additionally, the personal characteristics and professional orientation of the mentor determines the effectiveness of the mentoring that mentees receive. Critically, an effective mentorship programme will allow for opportunities to be created for the mentees to advance their business aspirations.

The finding on the positive feedback and growth underpins the relationship between the mentor and the mentee. This finding is congruent with that of Sambunjak et al. (2009), who explained that the relationship between the mentor and mentee transcends the initial objective and evolves into a peer relationship. These authors also explained that the mentoring process should be characterised by honesty, trust, mutual respect, open communication and confidentiality.

As previously explained, mentorship allows for the mentees to develop skills and knowledge in key aspects of business. The findings from the study show that the influence of mentorship on successful youth entrepreneurs can be done by entrepreneurs developing successful businesses, shaping career goals, opening networking channels and developing skills and competencies, improving self-confidence and developing the ability to be open-minded. Podsen and Denmark (2000) explain that goal setting is an important driver for successful mentorship and it has been identified as a pivotal aspect in an effective mentorship relationship that facilitates the development of independence, self-confidence, job satisfaction, upward mobility and decision-making/problem-solving skills in the protégé (Shrubbe, 2004).

Considering that both the hard skills such as improved networking, management and stakeholder engagements, and exposure to the product and market environment, and soft interpersonal qualities such as self-confidence and shaping of career, it can be concluded that there is a relationship between mentorship and successful youth entrepreneurship. This is a view that was also confirmed by all 20 participants of the study. The findings of the study align with the literature, as the literature explained that entrepreneurial mentoring training is also 
characterised as practical programmes that provide business management skills to entrepreneurs (Bechard \& Toulouse, 1998; Vesper, 1990). Within this process, there is a dispensing of practical skills and an acquisition of the attitudes required for effective management of a business venture (Rasheed \& Rasheed, 2007).

\section{Conclusion}

The aim of the study was to explore the relationship between mentorship and successful entrepreneurship. The study proved that there is a relationship between mentorship and successful entrepreneurship. The findings indicated that successful mentorship is characterised by a well-informed mentee with developed skills and knowledge. There was unanimous agreement among all the mentees and mentors that mentorship is critical for the success of youth entrepreneurs, as it plays a critical role in ensuring that youth entrepreneurs develop the necessary knowledge, skill and competencies to enhance their technical, managerial and personal growth capacity. Among these were networking abilities, managerial competencies, stakeholder engagements abilities, and knowledge about product and market environment dynamics as well as interpersonal qualities such as self-confidence and career shaping. Despite this, it was evident that the success of the mentorship relationship, itself, is not easy, as there were several inhibiting factors such as lack of information or awareness about the mentorship programme, lack of resources to conduct mentorship programmes, poor relationship dynamics between mentor and mentee, poor commitment from the mentor or mentee, and lack of capable mentors and role models However, mentorship can be a catalyst for youth entrepreneur success and this is essential for South Africa to achieve its objectives of decreasing unemployment, inequality, youth participation in the economy and poverty, with entrepreneurship as the driver for this achievement.

For mentorship to be successful, it is recommended that a clear mentorship programme be established, with a contract, clear goals and milestones including implementation and monitoring plans. It is further recommended that both mentors and mentees show a willingness and commitment to be part of the mentorship programme.

This study, like any research study, was not without limitations and, as a result, caution should be taken when using these results. This study was concentrated on one mentorship programme and gaps in its performance might transfer to how the mentor and mentee assess the success of the mentorship. This is because they will have the expectations and the outcomes of the programme as their baseline. Furthermore, the scope of study did not include 
an objective quantifiable measure of before and aftereffects of the mentorship programme, since a quantifiable measure was not the focus of the study.

Despite the limitation, the study contributed to the body of knowledge on entrepreneurship and will assist future students, academics and researchers in the field of business management. It will further help policymakers to make informed policy decisions with regard to youth entrepreneurship mentorship and the unemployment problem. It is recommended that a correlation study be conducted, to establish the relationship between mentorship and successful entrepreneurship.

\section{REFERENCES}

Aubert, J. (2014). Women entrepreneur revolution: Ready!Set!Launch! Bloomington, IN: Balboa Press.

Audet, J., \& Couteret, P. (2012). Coaching the entrepreneur: features and success factors. Journal of Small Business and Enterprise Development, 19(3), 515-531.

Barker, J.C., Rendon, H., and Janis, J.E. (2016). Medical student mentorship in plastic surgery: The mentee's perspective. Plast Reconstr Surg. 137,1934-1942.

Baldwin, J., Gray, T., Johnson, J., Proctor, J., Rafiquzzaman, M., and Sabourin, D. (1997). Les faillites d'entreprise au Canada. Rapport no. 61-525-XIF. Ottawa: Statistique Canada.

Beattie, R. (1999). The creative entrepreneur: A study of the entrepreneur's creative process. Frontiers of Entrepreneurship Research. Babson Park: Babson College.

Bechard, J.P. \& Toulouse, J.M. (1998). Validation of a didactic model for the analysis of training objectives in entrepreneurship. Journal of Business Venturing. 13(4), 317-332.

Beckett, B.J. (2010). Mentorship is key to career success. Strategic Finance, 21-22.

Bickel, J.\& Brown, A.J. (2005). Generation X: Implications for faculty recruitment and development in academic health centres. Academic Medicine, 80, 205-210

Bisk, L. (2002). Formal entrepreneurial mentoring: the efficacy of third-party managed programs. Career Development International, 7(5), 262-70.

Braun, V., \& Clarke, V. (2006). Using thematic analysis in psychology. Qualitative Research in Psychology, 3(2), 77-101.

Cohen, N.H. (2000). The Step-by-Step Guide to Starting an Effective Mentoring Program. Canada: HRD Press.

Connor, J. (2014). Is the 'science' of entrepreneurship hindering entrepreneurial growth in SA? The South African Institute of Professional Accountants Journal, 1(20).

Cranwell-Ward, J., Bossons, P., and Gover, S. (2004). Mentoring: A Henley review of best practice. Basingstoke: Palgrave Macmillan. 
Creswell, J. W. (2013). Philosophical assumptions and interpretive frameworks. Qualitative inquiry and research design: Choosing among five approaches. Thousand

Oaks, CA: Sage Publications. 15-41

Deakins, D \& Freel, M. (2006). Entrepreneurship and small firms. (4th ed.) London: McGrawHill.

Dinolfo, S., \& Nugent, J.S. (2010). Making mentoring works. Retrieved from http://www.catalyst.org/system/files/Making_Mentoring_Work.pdf

Dokou, G. K. (2001). Accompagnement entrepreneurial et construction des facteurs clés de succès. Xe Conférence de l'AIMS, Université Laval (Québec).

Ekpe, I., Razak, R. C., Ismail, M., and Abdullah, Z. (2016). Entrepreneurial skill acquisition, psycho-social factors and youth's self-employment in Malaysia. Journal of Entrepreneurship Education, 19 (2), 78-88.

Fadeyi, O., Oke, A.O., Ajagbe, M.A., Isiavwe, D.T., and Adegbuyi, A. (2015). Impact of youth entrepreneurship in nation-building. International Journal of Academic Research in Public Policy and Governance. 2(1), 27-40.

Fatoki, O. O., \& Chindoga, L. (2011). An Investigation into the Obstacles to Youth Entrepreneurship in South Africa. International Business Research. 4(2), 161-169.

Franklin, T., Turner, S., Kariuki, M., and Duran, M. (2001). Mentoring overcomes barriers to technology integration. Journal of Computing in Teacher Education. 18(1), 26-31.

Gallup. (2014). Life in college matters for life after college: New Gallup-Purdue study looks at links among college, work, and well-being. Retrieved from http://www.gallup.com/poll/ (Accessed 12 May 2018)

Gartner, W. B., Starr, J. A., and Bhat, S. (1999). Predicting new venture survival: an analysis of "anatomy of a start-up." cases from Inc. Magazine. Journal of Business Venturing. 14(2), 215-232.

Gaskill, L. R., Van Auken, H. E., and Manning, R. A. (1993). A factor analytic study of the perceived causes of small business failure. Journal of Small Business Management. 31(4), $18-31$.

Griffin, C. C., Winn, J. A., Otis-Wilborn, A., and Kilgore, K. L. (2003). New teacher induction in special education. (COPSSE Document Number RS-5). Gainesville, FL: University of Florida, Centre on Personnel Studies in Special Education.

Gudmastad, E. (2013). World Population Data Sheet 2013. (Online). Washington: PRB. Available at: http://www.prb.org/pdf13/2013-WPDS- infographic MED.pdf (Accessed 3 April 2018)

Haggard, D. L., Dougherty, T. W., Turban, D. B., and Wilbanks, J. E. (2011). Who is a mentor? A review of evolving definitions and implications for research. Journal of Management. 37, 280-304.

Herrington, M., Kew, J, and Mwanga, A. (2017). Global Entrepreneurship Monitor. South African Report 2016/2017. Cape Town: University of Cape Town, Graduate School of Business, Centre for Innovation and Entrepreneurship, p. 24 
Higgins A \& McCarthy M. (2005). Psychiatric nursing students' experiences of having a mentor during their first practice placement: an Irish perspective. Journal of Nurse Education in Practice. 5, 18-24.

Hisrich, R.D. \& Peters, M.P. (2002). Entrepreneurship (5th edition). McGraw-Hill Companies. New York. http://www.labour.gov.za/docs/policy/summit.html.

Hustedde R.J. (2018). Entrepreneurship and Economic Development in Rural America. In: Harley D., Ysasi N., Bishop M., Fleming A. (eds) Disability and Vocational Rehabilitation in Rural Settings. Springer, Cham

Jekielek, S.M., Moore, K.A., Hair, E.C. and Scarupa, H.J. (2002). "Mentoring: A Promising Strategy for Youth Development". Child Trends Research Brief. Washington D.C. 6.

Job Summit Declaration. (1998). Summary of Jobs Summit Declaration. Available at: www.labour.gov.za/doc/policy/summit.html

Klasen, N. \& Clutterbuck, D. (2002). Implementing Mentoring Schemes: A Practical Guide to Successful Programs. London: Butterworth-Heinemann.

Kubicek, A. (2015). Creating a Mentoring Culture for Organizational Success: A Guideline for Successful Mentoring Programs. Queen's University.

Kuhn, S, Milasi, S and Yoon, S. (2018). World employment social outlook: Trends 2018, World employment social outlook, ILO, Geneva. <http://www.ilo.org/global/research/globalreports/weso/2018/WCMS_615594/lang--en/index.htm>. (Accessed 29 January 2019)

Kyrgidou, L. P. \& Petridou, E. (2013). Developing women entrepreneurs' knowledge, skills, and attitudes through e-mentoring support. Journal of Small Business and Enterprise Development. 20 (3), 548 - 566.

Ladzani, W.M. \& Van Vuuren, J.J. (2002). Entrepreneurship training for emerging SMEs in South Africa. Journal of Small Business Management. 40(2),153-160.

Laukhuf, R.L. \& Malone, T.A. (2015). Women Entrepreneurs Need Mentors. International Journal of Evidence based coaching and Mentorship. 13(1),70-86.

Light, I., \& Bhachu. P. (2017). Immigration and entrepreneurship: Culture, capital and ethnic networks. London: Routledge, UK.

Maina, C.J. (2016). Factors influencing the success of youth entrepreneurship business startup: A case of Technoserve Stryde program in Nyeri country. United States International University.

Marco, C.A., \& Perina, D.G. (2004). Mentoring in Emergency Medicine: Challenges and Future Directions. Acad Emerg Med. 11,1329-30.

Mason, C. (2011). Entrepreneurship Education and Research: Emerging Trends and Concerns. (Online) Available at: https://ideas.repec.org/a/grg/02entp/v1y2011i1p13- 25.html (Accessed 19 February 2018)

Mckevitt, D., \& Marshall, D. (2015). The legitimacy of entrepreneurial mentoring. Journal of Entrepreneurial Behavior \& Research. 21(2), 263-280. http://doi.org/10.1108//JEBR-05-20140089 (Accessed 15 November 2018) 
Memon, J., Rozan, M. Z. A., Ismail, K., Uddin, M., and Daud, D. (2015). Mentoring an entrepreneur: Guide for a mentor. SAGE Open, January-Ma. 1-10. http://doi.org/10.1177/2158244015569666 (Accessed 15 November 2018)

Morrison, A. \& Bergin-Seers, S. (2002). Pro-growth small businesses: learning architecture. Journal of Management Development. 21(5), 388-400.

Morton-Cooper, A., \& Palmer, A. (2000). Mentoring, preceptorship and clinical supervision ( $2^{\text {nd }}$ ed.). Oxford: Blackwell Science.

Mowgli mentoring (2017). The mentoring effect on economic growth. St. Nicholas House Office G.04. 31-34. High Street Bristol BS1 2AW UK

Myall, M., Levett- Jones, T. and Lathlean, J. (2008). Mentorship in contemporary practice: the experiences of nursing students and practice mentors. Journal of Clinical Nursing. 17(18341842)

Olsen, L. (2011). Many professional women don't have mentors. U.S. News. (Online) Available at: http://money.usnews.com/money/blogs/outside-voice-careers/2011

Oracle Corporation. (2018). Annual report 2017.

Ozgen, E., \& Baron, R. A. (2007). Social sources of information in opportunity recognition: Effects of mentors, industry networks, and professional forums. Journal of business venturing. 22(2), 174-192.

Padilla, A., Mulvey, P.W., and Lunsford, L.G. (2010). Public leadership in The Organizational Contexts of Public Leadership, edited by J.A. Rameriz. 121-40. Hauppauge, NY: Nova Science Publishers.

Pelan, V. (2012). The difference between mentoring and coaching. Talent Management Magazine. Available at: http//people.cpp.com.pdf (Accessed 20 July 2016)

Podsen, I. J., \& Denmark, V. M. (2000). Coaching and mentoring first-year and student teachers. New York: Eye on Education

Pompa, C. (2012). Literature review on enterprise mentoring. ODI, UK. Retrieved from http://www.forsa-mena.org/fr/content/documents/Literature\%25 20review\%25 200n\%25 20enterprise\%25 20mentoring. Pdf (Accessed 10 October 2017)

Priyanto, S. H. \& Sandjojo, I. (2005). Relationship between entrepreneurial learning, entrepreneurial competencies and venture success: empirical study on SMEs. International Journal of Entrepreneurship and Innovation Management. 5(5/6), 454-468.

Raeesi R. Dastranj, M., Mohammadi, S. and Rasouli, E. (2013). Understanding the Interactions among the Barriers to Entrepreneurship Using Interpretive Structural Modelling, International Journal of Business and Management. 8(13).

Ragins, B.R. \& Kram, K.E. (2007). The Roots and Meaning of Mentoring, in The Handbook of Mentoring at Work: Theory, Research, and Practice, eds BR Ragins \& KE Kram, SAGE Publications, Los Angeles. 3-15. 
Ralph, E. (2009). Enhancing practicum/clinical supervision via "adaptive mentorship": A promising model. Presentation at Third Annual Conference on Teaching and Learning (Promoting Student Learning: Diversity and Student Success), Windsor, ON.

Rasheed, B.Y. \& Rasheed, H.S. (2007). Developing Entrepreneurial Characteristics in Youth: The effect of Education and Enterprise Experience. Emerald Group Publishing Limited. 4, $261-277$.

Rhodes, J. E. (2002). Stand by me: The risks and rewards of mentoring today's youth. Cambridge, MA: Harvard University Press.

Rhodes, J. E., Spencer, R., Keller, T. E., Liang, B., and Noam, G. (2006). A model for the influence of mentoring relationships on youth development. Journal of Community Psychology, 34(6),691-707. doi:10.1002/jcop.20124. (Accessed 20 July 2016)

Riverin, N. (2007). Strengthening Entrepreneurship, Innovation and Economic Development at Local Level. OECD LEED Trento Centre.

Sambunjak. D., Straus. S.E. and Marusic A. (2010). What Makes a Good Mentor-Mentee Relationship. JCOM. 17(4).

Sandberg, S. (2013). Lean in - women, work, and the will to lead. New York, NY: Alfred A. Knopf.

Saunders, S., Lewis, P. and Thornhill, A. (2016). Research methods for business students. Harlow: Pearson Education.

Scannapieco, M. \& Painter, K. (2014). Barriers to Implementing a Mentoring Program for Youth in Foster Care: Implications for Practice and Policy Innovation. Child Adolesc Soc Work J. 31, 163-180.

Schøtt T, Kew P \& Cheraghi M. (2015). Future Potential: A GEM Perspective on Youth Entrepreneurship 2015. GEM Consortium. Available at http://www.gemconsortium.org/report. (Accessed 20 July 2018)

Schwartz, S. E. O., Lowe, S. R. and Rhodes, J. E. (2012). Mentoring relationships and adolescent self-esteem. The Prevention Researcher. 19(2), 1720.

Shepherd, D. A. (2011). Multilevel entrepreneurship research: Opportunities for studying entrepreneurial decision making. Journal of Management. 37, 412-420

Schrubbe KF. (2004). Mentorship: A critical component for professional growth and academic success. J Dent Educ. 68, 324-328.

Srivastava, S.B. (2013). Network Intervention: A Field Experiment to Assess the Effects of Formal Mentoring on Workplace Networks. University of California, Berkeley Working Paper.

South African Government. (2015). National Youth Policy 2015 - 2020. Online: Available at: http://www.thepresidency.gov.za/MediaLib/Downloads/Home/Publications/YouthPublications NationalYouthPolicyPDF/NYP.pdf (Accessed 29 January 2018)

South African Government (2015). Department of Small Business Development strategic plan 2015 - 2019. Online: Available at: http://www.dsbd.gov.za/?wpdmpro=dsbd-strategic-plan2015-2019-part-2 (Accessed 18 May 2020) 
Stephens, J.P., Heaphy, E., and Dutton, J.E. (2012). High-quality connections in The Oxford Handbook of Positive Organizational Scholarship, edited by K.S. Cameron \& G.M. Spreitzer. 385-99. New York: Oxford Press.

St-Jean, E. \& Audet, J. (2009). Factors leading to satisfaction in mentoring scheme for Novice entrepreneurs. International Journal of Evidence Based Coaching and Mentoring. 7(1)148.

St-Jean, E. (2011). Mentor Functions for Novice Entrepreneurs. Academy of Entrepreneurship Journal. 17(1) 65-84.

St-Jean, E. \& Audet, J. (2012). The role of mentoring in the learning development of the novice entrepreneur. International Entrepreneurship and Management Journal. 8(1), 119-140.

St-Jean, E., \& Audet, J. (2013). The effect of Mentor intervention style in Novice Entrepreneur mentoring relationships - Mentoring \& Tutoring: Partnership in learning. 21(1), 96-119.

St-Jean, E., \& Mathieu, C. (2015). Developing attitudes towards an entrepreneurial career through mentoring: The mediating role of entrepreneurial self-efficacy. Journal of Career Development. 42, 325-338, 10.117770894845314568190 (Accessed 16 August 2018)

Statistics South Africa, (2018). Quarterly labour force survey Q2:2018, 2018. Pretoria: Statistics South Africa.

Straus, SE., Chatur. F. and Taylor. M. (2009). Issues in the Mentor-Mentee Relationship in Academic Medicine: A Qualitative Study. Academic Medicine. 84(1)

Sullivan, R. (2000). Entrepreneurial learning and mentoring. International Journal of Entrepreneurial Behaviour \& Research. 6(3), 160 - 175.

Telkom Mentorship program database (2018). Telkom South Africa.

Telkom SOC South Africa (2018). Available online: http://www.telkom.co.za/about us/companyprofile/company-profile.shtml (Accessed 18 November 2018)

The presidency (2015). National Youth Policy 2015- 2020: We are generation 2020. We don't want a hand out, we want a hand up! Available online: www.thepresidency.gov.za/download/file/fid/58 (accessed 15 June 2019)

Thurik, A.R., Carree, M.A., van Stel, A. and Audretsch, D.B. (2008). Does Self-Employment reduce unemployment? Journal of Business Venturing. 23(6), 673-686.

Van der Sijde, P. \& Weijman, G. (2013). Benefits and Impact of Mentoring for Entrepreneurs: The entrepreneur's perspective. International Journal of Human Resource Studies. 3(4).

Vesper, K.H. (1990). New Venture Strategies. Englewood Cliffs: Prentice-Hall. 


\section{ABOUT AUTHORS}

*Belinda Nomacilongo Tshehla

Master's student

Department of Business Management

College of Economic and Management Sciences

University of South Africa

E-mail: mabeegp@gmail.com

** King Costa

Research Professor and Executive Dean

Global Centre for Academic Research

E-mail: costak@researchglobal.net 